\title{
Cell Encapsulation Within Alginate Microcapsules: Immunological Challenges and Outlook
}

OPEN ACCESS

Edited by:

Nihal Engin Vrana,

Sparta Medical, France

Reviewed by:

Pinar Yilgor Huri,

Ankara University, Turkey

Gilson Khang,

Chonbuk National University,

South Korea

*Correspondence:

Gonzalo Hortelano

gonzalo.hortelano@nu.edu.kz

Specialty section:

This article was submitted to Biomaterials,

a section of the journal

Frontiers in Bioengineering and

Biotechnology

Received: 30 July 2019 Accepted: 15 November 2019 Published: 03 December 2019

Citation:

Ashimova A, Yegorov $S$, Negmetzhanov $B$ and Hortelano $G$ (2019) Cell Encapsulation Within

Alginate Microcapsules: Immunological Challenges and

Outlook.

Front. Bioeng. Biotechnol. 7:380. doi: 10.3389/fbioe.2019.00380

\author{
Assem Ashimova ${ }^{1}$, Sergey Yegorov ${ }^{1,2}$, Baurzhan Negmetzhanov ${ }^{1,3}$ and \\ Gonzalo Hortelano ${ }^{1 *}$
}

${ }^{1}$ Department of Biology, School of Science and Humanities, Nazarbayev University, Nur-Sultan, Kazakhstan, ${ }^{2}$ Department of Pedagogical Mathematics and Natural Science, Faculty of Education and Humanities, Suleyman Demirel University, Almaty, Kazakhstan, ${ }^{3}$ National Laboratory Astana, Center for Life Sciences, Nazarbayev University, Nur-Sultan, Kazakhstan

Cell encapsulation is a bioengineering technology that provides live allogeneic or xenogeneic cells packaged in a semipermeable immune-isolating membrane for therapeutic applications. The concept of cell encapsulation was first proposed almost nine decades ago, however, and despite its potential, the technology has yet to deliver its promise. The few clinical trials based on cell encapsulation have not led to any licensed therapies. Progress in the field has been slow, in part due to the complexity of the technology, but also because of the difficulties encountered when trying to prevent the immune responses generated by the various microcapsule components, namely the polymer, the encapsulated cells, the therapeutic transgenes and the DNA vectors used to genetically engineer encapsulated cells. While the immune responses induced by polymers such as alginate can be minimized using highly purified materials, the need to cope with the immunogenicity of encapsulated cells is increasingly seen as key in preventing the immune rejection of microcapsules. The encapsulated cells are recognized by the host immune cells through a bidirectional exchange of immune mediators, which induce both the adaptive and innate immune responses against the engrafted capsules. The potential strategies to cope with the immunogenicity of encapsulated cells include the selective diffusion restriction of immune mediators through capsule pores and more recently inclusion in microcapsules of immune modulators such as CXCL12. Combining these strategies with the use of well-characterized cell lines harboring the immunomodulatory properties of stem cells should encourage the incorporation of cell encapsulation technology in state-of-the-art drug development.

Keywords: alginate, cell encapsulation, microcapsule, immune response, therapeutic delivery, damageassociated molecular patterns, cytokines

\section{INTRODUCTION AND BRIEF HISTORY OF CELL ENCAPSULATION}

Cell microencapsulation is a strategy that allows the implantation of allogeneic and xenogeneic cells, while keeping the cells isolated from the host immune response by semipermeable membrane permitting the diffusion of gases, nutrients and therapeutics but not of host immune cells (Orive et al., 2003). The birth of encapsulation technology can be dated back to the 1934 report of Vincenzo Bisceglie describing the encapsulation of tumor cells in a polymer and transplanting the capsules 
into the abdominal cavity of a pig (Bisceglie, 1933). Later in 1964 Thomas Chang described the "artificial cell" concept and the idea of using semipermeable microcapsules to deliver therapeutics (Chang, 1964). Subsequently a pioneer preclinical trial was conducted using encapsulated pancreatic islets for diabetes (Lim and Sun, 1980). The islets stayed viable and showed in vivo therapeutic effect for 3 weeks in rats. Additional diabetes studies followed (Calafiore et al., 2006). The method has also been explored to deliver therapeutics for many other conditions: central nervous system delivery (Aebischer et al., 1996; Zurn et al., 2000; Garcia et al., 2010; Kuramoto et al., 2011; Luo et al., 2013), cancer (Lohr, 2001; Lohr et al., 2002; Dubrot et al., 2010), metabolic disorders (Hortelano et al., 1996; Garcia-Martin et al., 2002; Wen et al., 2006, 2007; Piller Puicher et al., 2012; Diel et al., 2018), and anemia (Orive et al., 2005) among multiple other conditions. Altogether, many applications of encapsulated cells have been described (Chang, 2019), leading to the creation of several biotechnology companies developing encapsulation devices (Orive et al., 2019).

In parallel, a wide variety of implantation sites have been explored, including intraperitoneal (Elliott et al., 2007), intratumoral (Lohr, 2001; Lohr et al., 2002), intrathecal (Aebischer et al., 1996), intraventricular (Ross et al., 2000), and intraocular (Orive et al., 2019), among others. Implantation sites are selected based on the needs of each specific medical condition, such as implantation of encapsulated mesenchymal cells secreting BMP-2 for bone regeneration (Turgeman et al., 2002; Tai et al., 2008). Encapsulation of pancreatic islets has been particularly explored, with numerous preclinical and clinical trials, several most remarkable examples of which are described below.

One of the first clinical trials to employ cell encapsulation demonstrated that insulin independence persisted for 9 months after intraperitoneal injection of encapsulated human islets in a type 1 diabetic patient (Soon-Shiong et al., 1994). In a different study, seven type 1 diabetes patients reached stable insulin independence after transplantation of encapsulated islets (Shapiro et al., 2000). Elliott et al. demonstrated the long-term viability and functionality of transplanted encapsulated islets in a 41-year old diabetic patient (Elliott et al., 2007). Veriter et al. co-encapsulated pig islets with mesenchymal stem cells (MSCs) and describe the improvement in implant oxygenation and neoangiogenesis (Veriter et al., 2014). One of the most recent studies reported a safe and successfull transplantation of porcine islets with a bioartificial pancreas device in diabetic primates in the absence of immune suppression (Ludwig et al., 2017).

\section{THE CHALLENGES ENCOUNTERED BY THE CELL ENCAPSULATION TECHNOLOGY}

Despite its attractive nature, no clinical licensed therapeutic product based on cell encapsulation technology has yet seen the market. While there are multiple reasons that explain why the technology has failed to deliver its promise, one of the greatest challenges has arguably been the host immune response elicited by both the implanted capsule and the encapsulated cells (De Vos et al., 1999; Paredes-Juarez et al., 2014b). The first contact of the capsule with the host occurs at the level of the polymer protecting the encapsulated cells (Figure 1). Next, the encapsulated cells themselves play a key role in inducing immune responses through antigen shedding and secretion of soluble immune mediators ( $\mathrm{Hu}$ and de Vos, 2019; Figure 1). Additionally, the transgenes expressed and secreted by the encapsulated cells are often recognized as foreign by the host, while the expression vector used to genetically engineer encapsulated cells may contain immunogenic sequences and moieties. Importantly, the cumulative effect of these elements may exceed the simple additive effect of the individual components.

\section{THE CAPSULE POLYMER: CHEMICAL COMPOSITION AND IMMUNOGENICITY}

Although numerous polymers have been described to protect encapsulated allo- or xenogeneic cells (de Vos et al., 2014; Hu and de Vos, 2019), alginate has been used the most, either alone or in combination with other polymers (de Vos et al., 2006; Goh et al., 2012). Alginate is a natural polysaccharide purified from algae (though it can also be produced by some bacteria), with excellent biocompatibility and biodegradability (Murua et al., 2008; Lee and Mooney, 2012; Gasperini et al., 2014) and a sound safety record (Orive et al., 2006). Alginate microcapsules implanted intraperitoneally in immunocompetent mice remain free and unattached to host tissues for months, and can be recovered using a simple spatula (Hortelano et al., 1996). Nevertheless, despite its biocompatibility, any impurities and endotoxins remaining after the purification process will act as adjuvants to trigger and/or enhance immune responses resulting in pericapsular fibrotic overgrowth post-implantation (Tam et al., 2006; Paredes-Juarez et al., 2013; Calafiore and Basta, 2014).

\section{Alginate}

Alginate is a block copolymer made of combinations of mannuronic acid (M) and guluronic acid (G) subunits (de Vos et al., 2014). Many different types of alginate are now commercially available. Factors such as the ratio of $M / G$, the length of the copolymers, the molecular weight and the alginate viscosity are important in determining the properties of the polymer (Tam et al., 2011; Kummerfeld et al., 2016). For instance, alginates that have high $G$ content have been shown to have better compatibility and are thus best suited for cell encapsulation applications (Uludag et al., 2000; Bhujbal et al., 2014; ParedesJuarez et al., 2014b).

The crosslinking of anionic alginate with cationic compounds such as poly-L-lysine (PLL) allows a more controlled pore size of the microcapsules (de Vos et al., 2002; van Hoogmoed et al., 2003; Tam et al., 2011; Kendall and Opara, 2017). In addition to PLL alternative crosslinking compounds such as barium (Liu et al., 2013; Paredes-Juarez et al., 2014b) or strontium (Morch et al., 2006) have also been described. However, unbound PLL affects the capsule biocompatibility (Paredes-Juarez et al., 2014b; Hajifathaliha et al., 2018) as shown by the presence of the 


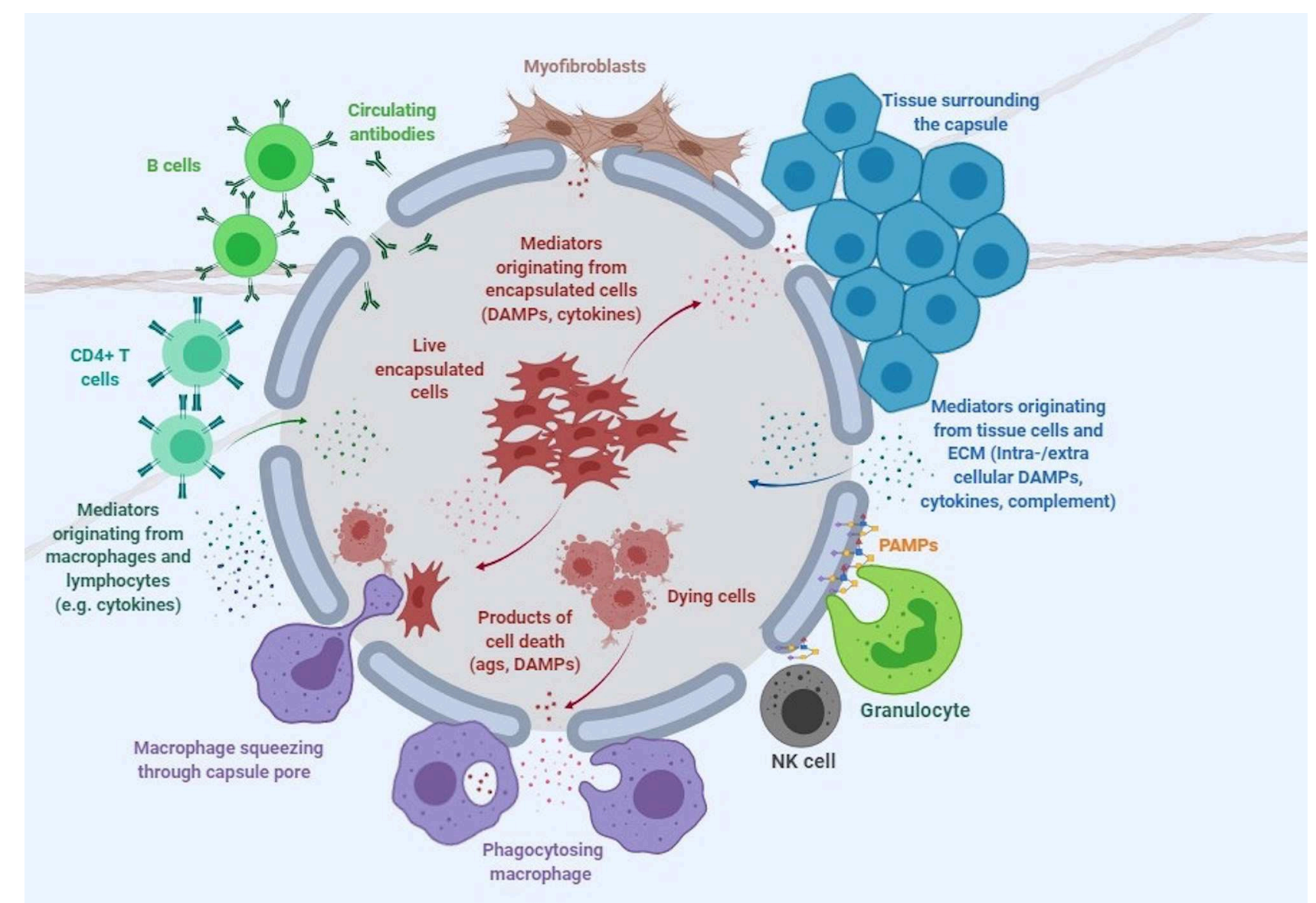

FIGURE 1 | Immune response to encapsulated cells. This cartoon depicts the complex interaction of microcapsules with the immune system and surrounding tissue environment. DAMPs, damage-associated molecular patterns; PAMPs, pathogen associated molecular patterns (see Table 1 and text for more detail).

pro-inflammatory cytokine tumor necrosis factor (TNF) in the supernatant of monocytes cultured with PLL (Strand et al., 2001).

\section{Polymer Immunogenicity}

The innate immune system recognizes pathogen associated molecular patterns (PAMPs) in alginate preparations through the pattern recognition receptors (PRR) (Paredes-Juarez et al., 2014a; Krishnan et al., 2017), resulting in proinflammatory cytokine release and adverse anti-capsular immune responses (Dorrington and Fraser, 2019). Toll-Like Receptors (TLRs) on the cell surface or within the intracellular endosomal compartment is one PRR type recognizing the PAMPs originating from non-mammalian cells. Despite extensive purification, alginates can still contain lipopolysaccharide that is recognized by TLR4 (Vaure and Liu, 2014), peptidoglycan and lipoteichoic acid sensed by TLR2 (Paredes-Juarez et al., 2014a) and small molecular poly-M residues detected by TLR2 and TLR4 (Flo et al., 2002). Thus, high quality purification of alginate becomes crucial for the long-term survival of encapsulated cells, and strategies to achieve high level of alginate purity have been described elsewhere (Paredes-Juarez et al., 2014a).

\section{ENCAPSULATED CELLS vS. THE HOST: EXCHANGE OF SIGNALING MOLECULES \\ Capsule Permeability}

The type of molecules that can pass through the capsular membrane is dictated by multiple factors, including the distribution and size of the capsule pores (e.g., alginate gel pores range from 5 to $150 \mathrm{~nm}$ ) and biochemical characteristics of the molecules, such as the molecule's molecular weight, size, shape and presence of charged groups. While the weight of the molecule is only partially responsible for the molecule's ability to diffuse in and out of the capsules, it is a useful parameter when comparing the ability of different signaling agents to influence the immune response against the capsules (Table 1). However, there is substantial heterogeneity in the literature regarding the permeability of alginate capsules. Thus, some researchers indicate that proteins up to $\sim 250 \mathrm{kDa}$ and polysaccharides up to $\sim 50 \mathrm{kDa}$ can diffuse through the pores of alginate capsules (Vaithilingam et al., 2011, 2013), while others report that their capsules are impermeable to proteins weighing $\sim 25 \mathrm{kDa}$ such as high mobility group box (HMGB)1 (Paredes-Juarez et al., 2015) or antibodies (Cui et al., 2009). This heterogeneity could at least in part be 
TABLE 1 | Intra- and Extra-cellular molecules that modulate immune responses to encapsulated cells.

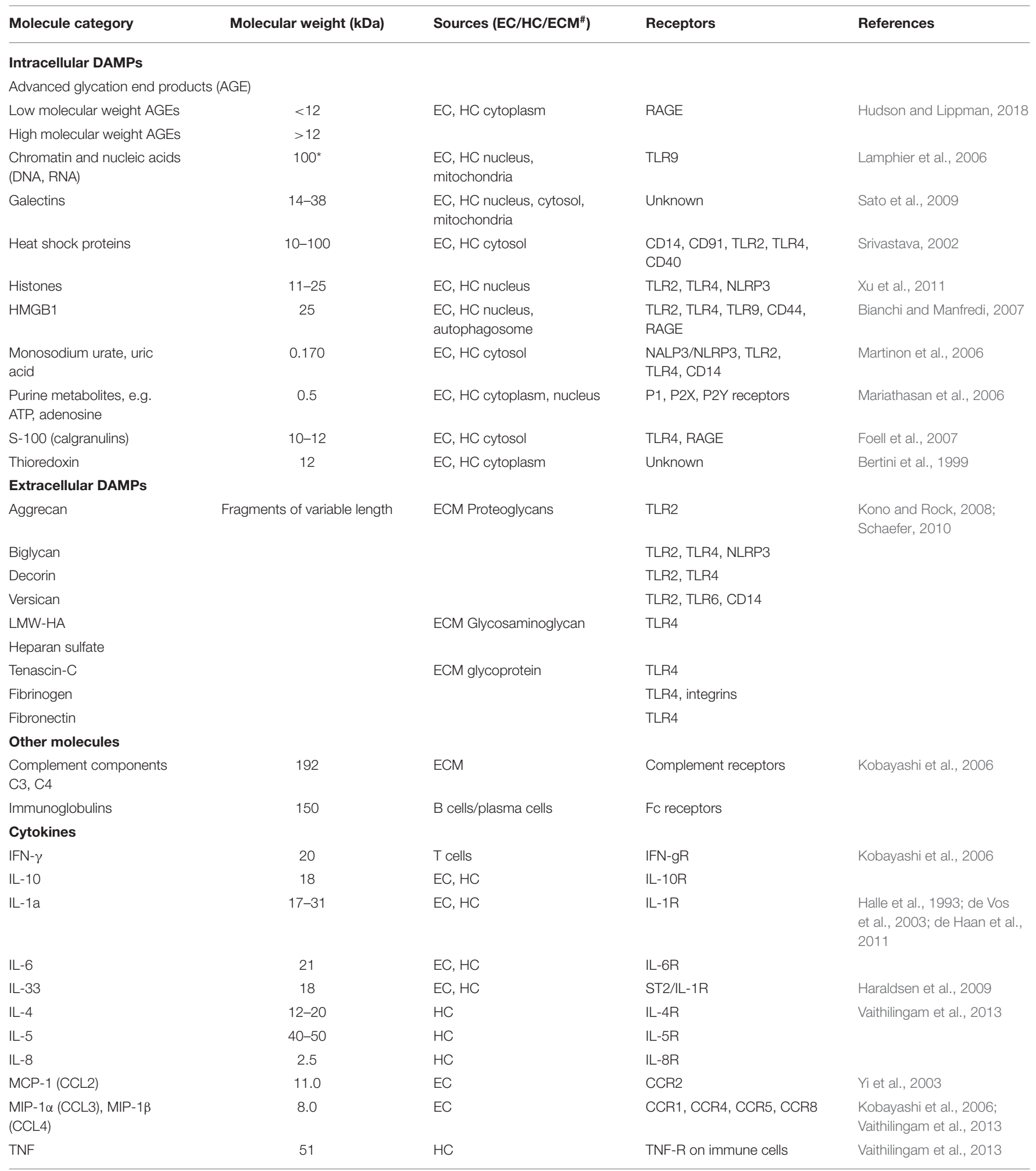

"Fragmented molecules' approximate average weight. ${ }^{*} E C$, encapsulated cells; HC, host cells; ECM, extracellular matrix; CD, cluster of differentiation; DAMP, damage-associated molecular pattern; HMGB1, high-mobility group protein B1; MCP, monocyte chemoattractant protein; LMW-HA, low molecular weight hyaluronan; IL, interleukin; TLR, toll-like receptor; NALP3, NACHT, LRR, and PYD domains-containing protein 3; NLRP, NOD-like receptor pyrin domain-containing; RAGE, receptor of advanced glycation end products. 
due to the inter-laboratory differences in capsule preparation protocols and cell encapsulation techniques resulting in variable biochemical characteristics and diameter of capsule pores. In practical terms this means that encapsulated cells can both produce immune mediators and respond to mediators from the host with critical implications for the success of the technology.

\section{Danger Signals Produced by Encapsulated Cells}

Live cells secrete numerous products of metabolism, some of which, such as advanced glycation end products (AGE) and uric acid can be recognized as damage-associated molecular patterns (DAMPs) by the host (Matzinger, 2002, 2007). When encapsulated cells undergo apo- or pyroptosis, they release other DAMPs, such as ATP, nucleic acids and chromatin fragments (Kono and Rock, 2008). In addition to macrophages, transplanted microcapsules attract granulocytes and myofibroblasts, which adhere to the capsule surface, and other immune cells such as natural killer (NK) cells, CD4+ T cells, and B cells (Candinas et al., 1996; Lin et al., 1997; Kobayashi et al., 2006; Cui et al., 2009; Figure 1).

Notably, the double stranded DNA used to genetically engineer cells is a DAMP recognized by TLR9 (Table 1). This recognition initiates a signal transduction pathway mediated through MyD88 that leads to the expression of pro-inflammatory cytokines such as interleukin (IL)-6, IL-8, TNF, as well as IFN $\alpha$ and IFN-inducible genes. A successful strategy to minimize this activation of the innate immune system is to eliminate the unmethylated $\mathrm{CpG}$ sequences present in the vector DNA, which led to a significant reduction in the titer of antibodies to the transgene (Reyes-Sandoval and Ertl, 2004). Thus, care should be taken to genetically engineer encapsulated cells with vectors that minimize DAMP generation.

Our understanding of the immune mechanisms causing encapsulated cell rejection is still incomplete. Therefore, future studies should aim to perform a high throughput screening of molecules and cells in and outside the capsule using dynamic imaging, proteomic and metabolomic assays. Meanwhile, the type of encapsulated cells should be chosen wisely to minimize the capsule immunogenicity.

\section{THE TYPE OF ENCAPSULATED CELLS: CHOICE THAT MATTERS}

Ideal candidates for encapsulation would be non-immunogenic, non-tumorigenic, free from ethical controversies, easy to obtain and plentiful, well-characterized and reproducible. A plethora of different cell types has been used for encapsulation, each with its unique advantages and limitations (Uludag et al., 2000; TomaroDuchesneau et al., 2013). The first consideration in cell selection is its immunogenicity, arguably the most critical factor. At times, the choice of cells is limited by the ability to express a unique therapeutic molecule. The use of encapsulated cells for diabetes is a good example, since the sophisticated regulation of insulin expression in response to glucose is restricted to pancreatic $\beta$ cells (Kieffer et al., 2017; Vaithilingam et al., 2017; Zhong and Jiang, 2019). The existing autoimmune response against pancreatic islets in diabetic patients makes these cells highly immunogenic, and thus a formidable challenge to overcome (Alagpulinsa et al., 2019).

\section{The Case of $\mathrm{C2C} 12$ vs. G8 Myoblasts}

Our group previously evaluated the immunogenic nature of encapsulated $\mathrm{C} 2 \mathrm{C} 12$ murine myoblasts expressing human coagulation IX (FIX), which is considered a rather weak antigen. Compared with mice immunized with FIX protein in complete Freund's adjuvant (a standard for immunization), mice transplanted with microencapsulated cells had a much higher antibody titer to FIX (Gomez-Vargas et al., 2004). Furthermore, encapsulated cells also stimulated vigorous cellular immune responses to FIX, including cytotoxic T lymphocytes (CTL), and induced neutralizing antibodies, a feat Freunds' adjuvant was unable to achieve. The unique ability of the microcapsules to allow the permeability of immune mediators but not of cells leads to a continuous supply of transgene that stimulates the immune system (Gomez-Vargas et al., 2004).

When the C2C12 cell line was substituted with G8 murine myoblasts of fetal origin, mice receiving G8 cells expressing FIX did not develop antibodies to FIX, showing instead a sustained systemic delivery of FIX (Wen et al., 2007). These contrasting results indicate the critical importance of the cell type used, and the need to seek non-immunogenic cells. Fetal cells do not express MHC class antigens like adult differentiated cells (Machado Cde et al., 2013), and thus are not able to induce a comparable immune response.

\section{The Transgene}

On the other hand, the immunogenicity of each transgene used to engineer encapsulated cells is unique, and results obtained with a given transgene cannot be extrapolated to other transgenes. Microencapsulated G8 myoblasts did not elicit antibodies to FIX (Wen et al., 2007), but they did induce antibodies to FVIII, a more immunogenic protein (Garcia-Martin et al., 2002). In contrast, encapsulated $\mathrm{C} 2 \mathrm{C} 12$ resulted in effective long-term release of erythropoietin in mice, which induced increased hematocrit level for more than 100 days (Orive et al., 2005). Therefore, the immunogenicity of the cells and the transgene are not necessarily independent from each other and the development of antibodies against the transgene cannot be easily generalized or assumed.

\section{Cell Proliferation Inside Microcapsules}

Another important consideration is the proliferation of cells in the polymeric matrix. Ideally, cells should be proliferative but would have contact inhibition to prevent uncontrolled proliferation. Excessive proliferation and high cell density affects nutrient permeability, which reduces cell viability. In this regard, myoblasts can proliferate temporarily in alginate capsules, after which they become quiescent (Hortelano et al., 1999, 2001), while fibroblasts continue to proliferate long after encapsulation (Liu et al., 1993). Pancreatic islet cells represent a unique case since they do not proliferate once encapsulated (Dufrane and Gianello, 2012). Ultimately this lack of proliferation reduces 
cell viability and the therapeutic efficacy of the microcapsules (Barkai et al., 2016).

\section{Using Encapsulated Stem Cells}

Recent exciting protocols for obtaining stem cells or inducing pluripotent stem cells from adult cells have opened new possibilities for encapsulation (Tabar and Studer, 2014). Stem cells have attractive immunomodulatory properties (Liu et al., 2017), are not highly proliferative and are suitable for longterm transplantation (Goren et al., 2010; Mandal et al., 2019). However, the viability of human mesenchymal stem cells (hMSCs) in alginate microcapsules is not optimal. We, and others, have decorated alginate with peptides or proteins that improve the cellular attachment of hMSCs on alginate (Yu et al., 2010; Sayyar et al., 2012, 2014, 2015). The addition of the amino acid residue RGD, fibrinogen or fibronectin enhanced cell viability, proliferation and/or transgene expression, as well as modulate stem cell differentiation. Therefore, stem cells are now seen upon as a very promising option for encapsulation. The recent use of a human stem cell line for encapsulation (Alagpulinsa et al., 2019) opens the possibility to genetically engineer an immortal cell line that can be thoroughly characterized and used as an off-the-shelf drug for a variety of patients.

\section{Novel Strategies to Reduce Immunogenicity of Microcapsules}

Recently, the incorporation of chemokine (C-X-C motif) ligand (CXCL12) into alginate by Alagpulinsa et al. (2019) remarkably resulted in no pericapsular fibrotic overgrowth after the xenotransplantation of human stem cells differentiated into pancreatic $\beta$ cells (SC- $\beta$ cells) in immunocompetent mice for $>150$ days without the need for immunosuppression. CXCL12 (or stromal cell-derived factor- $1 \alpha, \mathrm{SD}-1$ ) is the ligand for a transmembrane chemokine receptor CXCR4 (Klein and Rubin, 2004; Guyon, 2014; Janssens et al., 2018) that plays a key role in many biological processes including tumor metastasis, as well as cell angiogenesis, survival and migration (Liekens et al., 2010). CXCL12 attracts regulatory $\mathrm{T}$ cells (Tregs) and can modulate immune responses by abrogating immune surveillance

\section{REFERENCES}

Aebischer, P., Pochon, N. A., Heyd, B., Deglon, N., Joseph, J. M., Zurn, A. D., et al. (1996). Gene therapy for amyotrophic lateral sclerosis (ALS) using a polymer encapsulated xenogenic cell line engineered to secrete hCNTF. Hum. Gene Ther. 7, 851-860. doi: 10.1089/hum.1996.7.7-851

Alagpulinsa, D. A., Cao, J. J. L., Driscoll, R. K., Sirbulescu, R. F., Penson, M. F. E., Sremac, M., et al. (2019). Alginate-microencapsulation of human stem cell-derived beta cells with CXCL12 prolongs their survival and function in immunocompetent mice without systemic immunosuppression. Am. J. Transplant. 19, 1930-1940. doi: 10.1111/ajt.15308

Barkai, U., Rotem, A., and de Vos, P. (2016). Survival of encapsulated islets: more than a membrane story. World J. Transplant. 6, 69-90. doi: 10.5500/wjt.v6.i1.69

Bertini, R., Howard, O. M., Dong, H. F., Oppenheim, J. J., Bizzarri, C., Sergi, R., et al. (1999). Thioredoxin, a redox enzyme released in infection and inflammation, is a unique chemoattractant for neutrophils, monocytes, and $\mathrm{T}$ cells. J. Exp. Med. 189, 1783-1789. doi: 10.1084/jem.189.11.1783
(Susek et al., 2018; Yu et al., 2019) and repelling effector immune cells from the capsules (Chen et al., 2015). This novel strategy may open new horizons for therapeutic applications of encapsulated cells.

\section{CONCLUSION AND FUTURE OUTLOOK}

The concept of transplanting cells with therapeutic potential enclosed in polymeric microcapsules is highly relevant for the modern pharmaceutical industry. However, a major barrier to implementing cell encapsulation technology in the clinical setting is the immune response generated against the microcapsules and their contents. Therefore, a thorough characterization of the immune mechanisms involved in anti-capsular response is important for successful in vivo implementation of the technology. Despite the challenges, the recent use of immune modulators to avoid fibrotic overgrowth is an exciting and potentially game-changing development. Together with the rigorous polymer purification protocols available today and the use of human stem cell lines it may provide the final missing element for successful cell encapsulation applications. These recent developments should encourage clinical trials with renewed hopes for the field of cell encapsulation.

\section{AUTHOR CONTRIBUTIONS}

AA and GH conceived and wrote the first draft of the review. SY drew the figure, compiled the table, and wrote the immunology sections. AA and BN performed literature search and compiled references. All authors contributed to the writing of the manuscript, critically reviewed the manuscript draft, and approved the final version of the article.

\section{ACKNOWLEDGMENTS}

We would like to acknowledge the support of ORAU research funding to GH. AA receives NUIG graduate scholarship support from Nazarbayev University. The manuscript figure was created with BioRender.com.
Bhujbal, S. V., Paredes-Juarez, G. A., Niclou, S. P., and de Vos, P. (2014). Factors influencing the mechanical stability of alginate beads applicable for immunoisolation of mammalian cells. J. Mech. Behav. Biomed. Mater. 37, 196-208. doi: 10.1016/j.jmbbm.2014.05.020

Bianchi, M. E., and Manfredi, A. A. (2007). High-mobility group box 1 (HMGB1) protein at the crossroads between innate and adaptive immunity. Immunol. Rev. 220, 35-46. doi: 10.1111/j.1600-065X.2007.00574.x

Bisceglie, V. (1933). Uber die antineoplastische immunitat; heterologe Einpflnzung von Tumoren in Huhner-embryonen. Ztschr. Krebsforsch. 40, 122-140. doi: $10.1007 / \mathrm{BF} 01636399$

Calafiore, R., and Basta, G. (2014). Clinical application of microencapsulated islets: actual prospectives on progress and challenges. Adv. Drug Deliv. Rev. 67-68, 84-92. doi: 10.1016/j.addr.2013.09.020

Calafiore, R., Basta, G., Luca, G., Lemmi, A., Racanicchi, L., Mancuso, F., et al. (2006). Standard technical procedures for microencapsulation of human islets for graft into nonimmunosuppressed patients with type 1 diabetes mellitus. Transplant. Proc. 38, 1156-1157. doi: 10.1016/j.transproceed.2006.03.014 
Candinas, D., Belliveau, S., Koyamada, N., Miyatake, T., Hechenleitner, P., Mark, W., et al. (1996). T cell independence of macrophage and natural killer cell infiltration, cytokine production, and endothelial activation during delayed xenograft rejection. Transplantation 62, 1920-1927. doi: 10.1097/00007890-199612270-00042

Chang, T. M. (1964). Semipermeable microcapsules. Science 146, 524-525. doi: $10.1126 /$ science. 146.3643 .524

Chang, T. M. S. (2019). Artificial cell evolves into nanomedicine, biotherapeutics, blood substitutes, drug delivery, enzyme/gene therapy, cancer therapy, cell/stem cell therapy, nanoparticles, liposomes, bioencapsulation, replicating synthetic cells, cell encapsulation/scaffold, biosorbent/immunosorbent haemoperfusion/plasmapheresis, regenerative medicine, encapsulated microbe, nanobiotechnology, nanotechnology. Artif. Cells Nanomed. Biotechnol. 47, 997-1013. doi: 10.1080/21691401.2019.1577885

Chen, T., Yuan, J., Duncanson, S., Hibert, M. L., Kodish, B. C., Mylavaganam, G., et al. (2015). Alginate encapsulant incorporating CXCL12 supports long-term allo- and xenoislet transplantation without systemic immune suppression. Am. J. Transplant. 15, 618-627. doi: 10.1111/ajt.13049

Cui, H., Tucker-Burden, C., Cauffiel, S. M., Barry, A. K., Iwakoshi, N. N., Weber, C. J., et al. (2009). Long-term metabolic control of autoimmune diabetes in spontaneously diabetic nonobese diabetic mice by nonvascularized microencapsulated adult porcine islets. Transplantation 88, 160-169. doi: 10.1097/TP.0b013e3181abbfc1

de Haan, B. J., Rossi, A., Faas, M. M., Smelt, M. J., Sonvico, F., Colombo, P., et al. (2011). Structural surface changes and inflammatory responses against alginate-based microcapsules after exposure to human peritoneal fluid. J. Biomed. Mater. Res. A 98, 394-403. doi: 10.1002/jbm.a. 33123

de Vos, P., Faas, M. M., Strand, B., and Calafiore, R. (2006). Alginate-based microcapsules for immunoisolation of pancreatic islets. Biomaterials 27, 5603-5617. doi: 10.1016/j.biomaterials.2006.07.010

de Vos, P., Hoogmoed, C. G., and Busscher, H. J. (2002). Chemistry and biocompatibility of alginate-PLL capsules for immunoprotection of mammalian cells. J. Biomed. Mater. Res. 60, 252-259. doi: 10.1002/jbm. 10060

de Vos, P., Lazarjani, H. A., Poncelet, D., and Faas, M. M. (2014). Polymers in cell encapsulation from an enveloped cell perspective. Adv. Drug Deliv. Rev. 67-68, 15-34. doi: 10.1016/j.addr.2013.11.005

de Vos, P., Van Hoogmoed, C. G., Van Zanten, J., Netter, S., Strubbe, J. H., and Busscher, H. J. (2003). Long-term biocompatibility, chemistry, and function of microencapsulated pancreatic islets. Biomaterials 24, 305-312. doi: 10.1016/S0142-9612(02)00319-8

De Vos, P., Van Straaten, J. F., Nieuwenhuizen, A. G., de Groot, M., Ploeg, R. J., De Haan, B. J., et al. (1999). Why do microencapsulated islet grafts fail in the absence of fibrotic overgrowth? Diabetes 48, 1381-1388. doi: $10.2337 /$ diabetes.48.7.1381

Diel, D., Lagranha, V. L., Schuh, R. S., Bruxel, F., Matte, U., and Teixeira, H. F. (2018). Optimization of alginate microcapsules containing cells overexpressing $\alpha$-l-iduronidase using Box-Behnken design. Eur. J. Pharm. Sci. 111, 29-37. doi: 10.1016/j.ejps.2017.09.004

Dorrington, M. G., and Fraser, I. D. C. (2019). NF-кB signaling in macrophages: dynamics, crosstalk, and signal integration. Front. Immunol. 10:705. doi: 10.3389/fimmu.2019.00705

Dubrot, J., Portero, A., Orive, G., Hernandez, R. M., Palazon, A., Rouzaut, A., et al. (2010). Delivery of immunostimulatory monoclonal antibodies by encapsulated hybridoma cells. Cancer Immunol. Immunother. 59, 1621-1631. doi: $10.1007 / \mathrm{s} 00262-010-0888-\mathrm{z}$

Dufrane, D., and Gianello, P. (2012). Macro- or microencapsulation of pig islets to cure type 1 diabetes. World J. Gastroenterol. 18, 6885-6893. doi: 10.3748/wjg.v18.i47.6885

Elliott, R. B., Escobar, L., Tan, P. L., Muzina, M., Zwain, S., and Buchanan, C. (2007). Live encapsulated porcine islets from a type 1 diabetic patient $9.5 \mathrm{yr}$ after xenotransplantation. Xenotransplantation 14, 157-161. doi: 10.1111/j.1399-3089.2007.00384.x

Flo, T. H., Ryan, L., Latz, E., Takeuchi, O., Monks, B. G., Lien, E., et al. (2002). Involvement of toll-like receptor (TLR) 2 and TLR4 in cell activation by mannuronic acid polymers. J. Biol. Chem. 277, 35489-35495. doi: 10.1074/jbc.M201366200
Foell, D., Wittkowski, H., Vogl, T., and Roth, J. (2007). S100 proteins expressed in phagocytes: a novel group of damage-associated molecular pattern molecules. J. Leukoc. Biol. 81, 28-37. doi: 10.1189/jlb.0306170

Garcia, P., Youssef, I., Utvik, J. K., Florent-Bechard, S., Barthelemy, V., Malaplate-Armand, C., et al. (2010). Ciliary neurotrophic factor cellbased delivery prevents synaptic impairment and improves memory in mouse models of Alzheimer's disease. J. Neurosci. 30, 7516-7527. doi: 10.1523/JNEUROSCI.4182-09.2010

Garcia-Martin, C., Chuah, M. K., Van Damme, A., Robinson, K. E., Vanzieleghem, B., Saint-Remy, J. M., et al. (2002). Therapeutic levels of human factor VIII in mice implanted with encapsulated cells: potential for gene therapy of haemophilia A. J. Gene Med. 4, 215-223. doi: 10.1002/jgm.248

Gasperini, L., Mano, J. F., and Reis, R. L. (2014). Natural polymers for the microencapsulation of cells. J. R. Soc. Interface 11:20140817. doi: $10.1098 /$ rsif.2014.0817

Goh, C. H., Heng, P. W. S., and Chan, L. W. (2012). Alginates as a useful natural polymer for microencapsulation and therapeutic applications. Carbohydr. Polym. 88, 1-12. doi: 10.1016/j.carbpol.2011.11.012

Gomez-Vargas, A., Rosenthal, K. L., McDermott, M. R., and Hortelano, G. (2004). Continuous antigenic stimulation system (CASS) as a new immunization strategy. Vaccine 22, 3902-3910. doi: 10.1016/j.vaccine.2004.04.010

Goren, A., Dahan, N., Goren, E., Baruch, L., and Machluf, M. (2010). Encapsulated human mesenchymal stem cells: a unique hypoimmunogenic platform for long-term cellular therapy. FASEB J. 24, 22-31. doi: 10.1096/fj.09-131888

Guyon, A. (2014). CXCL12 chemokine and its receptors as major players in the interactions between immune and nervous systems. Front. Cell. Neurosci. 8:65. doi: 10.3389/fncel.2014.00065

Hajifathaliha, F., Mahboubi, A., Nematollahi, L., Mohit, E., and Bolourchian, N. (2018). Comparison of different cationic polymers efficacy in fabrication of alginate multilayer microcapsules. Asian J. Pharm. Sci. 20:38 doi: 10.1016/j.ajps.2018.11.007

Halle, J. P., Bourassa, S., Leblond, F. A., Chevalier, S., Beaudry, M., Chapdelaine, A., et al. (1993). Protection of islets of Langerhans from antibodies by microencapsulation with alginate-poly-L-lysine membranes. Transplantation 55, 350-354. doi: 10.1097/00007890-199302000-00023

Haraldsen, G., Balogh, J., Pollheimer, J., Sponheim, J., and Kuchler, A. M. (2009). Interleukin-33 - cytokine of dual function or novel alarmin? Trends Immunol. 30, 227-233. doi: 10.1016/j.it.2009.03.003

Hortelano, G., Al-Hendy, A., Ofosu, F. A., and Chang, P. L. (1996). Delivery of human factor IX in mice by encapsulated recombinant myoblasts: a novel approach towards allogeneic gene therapy of hemophilia B. Blood 87, 5095-5103. doi: 10.1182/blood.V87.12.5095.bloodjournal87125095

Hortelano, G., Wang, L., Xu, N., and Ofosu, F. A. (2001). Sustained and therapeutic delivery of factor IX in nude haemophilia B mice by encapsulated C2C12 myoblasts: concurrent tumourigenesis. Haemophilia 7, 207-214. doi: 10.1046/j.1365-2516.2001.00492.x

Hortelano, G., Xu, N., Vandenberg, A., Solera, J., Chang, P. L., and Ofosu, F. A. (1999). Persistent delivery of factor IX in mice: gene therapy for hemophilia using implantable microcapsules. Hum. Gene Ther. 10, 1281-1288. doi: 10.1089/10430349950017969

$\mathrm{Hu}, \mathrm{S}$., and de Vos, P. (2019). Polymeric approaches to reduce tissue responses against devices applied for islet-cell encapsulation. Front. Bioeng. Biotechnol. 7:134. doi: 10.3389/fbioe.2019.00134

Hudson, B. I., and Lippman, M. E. (2018). Targeting RAGE signaling in inflammatory disease. Annu. Rev. Med. 69, 349-364. doi: 10.1146/annurev-med-041316-085215

Janssens, R., Struyf, S., and Proost, P. (2018). The unique structural and functional features of CXCL12. Cell. Mol. Immunol. 15, 299-311. doi: $10.1038 / \mathrm{cmi} .2017 .107$

Kendall, W. F. Jr., and Opara, E. C. (2017). Polymeric materials for permselective coating of alginate microbeads. Methods Mol. Biol. 1479, 95-109. doi: 10.1007/978-1-4939-6364-5_7

Kieffer, T. J., Woltjen, K., Osafune, K., Yabe, D., and Inagaki, N. (2017). Beta-cell replacement strategies for diabetes. J. Diabetes Invest. 9, 457-463. doi: $10.1111 /$ jdi. 12758

Klein, R. S., and Rubin, J. B. (2004). Immune and nervous system CXCL12 and CXCR4: parallel roles in patterning and plasticity. Trends Immunol. 25, 306-314. doi: 10.1016/j.it.2004.04.002 
Kobayashi, T., Harb, G., Rajotte, R. V., Korbutt, G. S., Mallett, A. G., Arefanian, H., et al. (2006). Immune mechanisms associated with the rejection of encapsulated neonatal porcine islet xenografts. Xenotransplantation 13, 547-559. doi: 10.1111/j.1399-3089.2006.00349.x

Kono, H., and Rock, K. L. (2008). How dying cells alert the immune system to danger. Nat. Rev. Immunol. 8, 279-289. doi: 10.1038/nri2215

Krishnan, R., Ko, D., Foster, C. E., Liu, W., Smink, A. M., de Haan, B., et al. (2017). Immunological challenges facing translation of alginate encapsulated porcine islet xenotransplantation to human clinical trials. Methods Mol. Biol. 1479, 305-333. doi: 10.1007/978-1-4939-6364-5_24

Kummerfeld, G., Nair, A., Ko, S., Krishnan, R., Lee, S., Alexander, M., et al. (2016). "Alginate composition, temperature, and presence of islet tissue influence microcapsule permeability," in Frontiers in Bioengineering and Biotechnology. Conference Abstract: 10th World Biomaterials Congress. (Montréal, QC). doi: 10.3389/conf.FBIOE.2016.01.03002

Kuramoto, S., Yasuhara, T., Agari, T., Kondo, A., Jing, M., Kikuchi, Y., et al. (2011). BDNF-secreting capsule exerts neuroprotective effects on epilepsy model of rats. Brain Res. 1368, 281-289. doi: 10.1016/j.brainres.2010.10.054

Lamphier, M. S., Sirois, C. M., Verma, A., Golenbock, D. T., and Latz, E. (2006). TLR9 and the recognition of self and non-self nucleic acids. Ann. N. Y. Acad. Sci. 1082, 31-43. doi: 10.1196/annals.1348.005

Lee, K. Y., and Mooney, D. J. (2012). Alginate: properties and biomedical applications. Prog. Polym. Sci. 37, 106-126. doi: 10.1016/j.progpolymsci.2011.06.003

Liekens, S., Schols, D., and Hatse, S. (2010). CXCL12-CXCR4 axis in angiogenesis, metastasis and stem cell mobilization. Curr. Pharm. Des. 16, 3903-3920. doi: $10.2174 / 138161210794455003$

Lim, F., and Sun, A. M. (1980). Microencapsulated islets as bioartificial endocrine pancreas. Science 210, 908-910. doi: 10.1126/science.6776628

Lin, Y., Vandeputte, M., and Waer, M. (1997). Natural killer cell- and macrophagemediated rejection of concordant xenografts in the absence of $\mathrm{T}$ and $\mathrm{B}$ cell responses. J. Immunol. 158, 5658-5667.

Liu, H. W., Ofosu, F. A., and Chang, P. L. (1993). Expression of human factor IX by microencapsulated recombinant fibroblasts. Hum. Gene Ther. 4, 291-301. doi: 10.1089/hum.1993.4.3-291

Liu, X., Li, W., Fu, X., and Xu, Y. (2017). The immunogenicity and immune tolerance of pluripotent stem cell derivatives. Front. Immunol. 8:645. doi: 10.3389/fimmu.2017.00645

Liu, Y., Tong, Y., Wang, S., Deng, Q., and Chen, A. (2013). Influence of different divalent metal ions on the properties of alginate microcapsules and microencapsulated cells. J. Sol-Gel Sci. Technol. 67, 66-76. doi: $10.1007 /$ s10971-013-3051-4

Lohr, J. M. (2001). The genes in pancreatic carcinoma. Pancreatology 1, 563-564. doi: $10.1159 / 000055863$

Lohr, J. M., Saller, R., Salmons, B., and Gunzburg, W. H. (2002). Microencapsulation of genetically engineered cells for cancer therapy. Methods Enzymol. 346, 603-618. doi: 10.1016/S0076-6879(02)46080-6

Ludwig, B., Ludwig, S., Steffen, A., Knauf, Y., Zimerman, B., Heinke, S., et al. (2017). Favorable outcome of experimental islet xenotransplantation without immunosuppression in a nonhuman primate model of diabetes. Proc. Natl. Acad. Sci. U.S.A. 114, 11745-11750. doi: 10.1073/pnas.1708420114

Luo, X. M., Lin, H., Wang, W., Geaney, M. S., Law, L., Wynyard, S., et al. (2013). Recovery of neurological functions in non-human primate model of Parkinson's disease by transplantation of encapsulated neonatal porcine choroid plexus cells. J. Parkinsons Dis. 3, 275-291. doi: 10.3233/JPD-130214

Machado Cde, V., Telles, P. D., and Nascimento, I. L. (2013). Immunological characteristics of mesenchymal stem cells. Rev. Bras. Hematol. Hemoter. 35, 62-67. doi: 10.5581/1516-8484.20130017

Mandal, S., Arfuso, F., Sethi, G., Dharmarajan, A., and Warrier, S. (2019). Encapsulated human mesenchymal stem cells (eMSCs) as a novel anti-cancer agent targeting breast cancer stem cells: Development of 3D primed therapeutic MSCs. Int. J. Biochem. Cell Biol. 110, 59-69. doi: 10.1016/j.biocel.2019.02.001

Mariathasan, S., Weiss, D. S., Newton, K., McBride, J., O’Rourke, K., Roose-Girma, M., et al. (2006). Cryopyrin activates the inflammasome in response to toxins and ATP. Nature 440, 228-232. doi: 10.1038/nature04515

Martinon, F., Petrilli, V., Mayor, A., Tardivel, A., and Tschopp, J. (2006). Goutassociated uric acid crystals activate the NALP3 inflammasome. Nature 440, 237-241. doi: 10.1038/nature04516
Matzinger, P. (2002). The danger model: a renewed sense of self. Science 296, 301-305. doi: 10.1126/science.1071059

Matzinger, P. (2007). Friendly and dangerous signals: is the tissue in control? Nat. Immunol. 8, 11-13. doi: 10.1038/ni0107-11

Morch, Y. A., Donati, I., Strand, B. L., and Skjak-Braek, G. (2006). Effect of Ca2 ${ }^{+}$ $\mathrm{Ba}^{+}$, and $\mathrm{Sr}^{+}$on alginate microbeads. Biomacromolecules $7,1471-1480$. doi: $10.1021 / \mathrm{bm} 060010 \mathrm{~d}$

Murua, A., Portero, A., Orive, G., Hernandez, R. M., de Castro, M., and Pedraz, J. L. (2008). Cell microencapsulation technology: towards clinical application. J. Control. Release 132, 76-83. doi: 10.1016/j.jconrel.2008. 08.010

Orive, G., De Castro, M., Ponce, S., Hernandez, R. M., Gascon, A. R., Bosch, M., et al. (2005). Long-term expression of erythropoietin from myoblasts immobilized in biocompatible and neovascularized microcapsules. Mol. Ther. 12, 283-289. doi: 10.1016/j.ymthe.2005.04.002

Orive, G., Hernandez, R. M., Gascon, A. R., Calafiore, R., Chang, T. M., De Vos, P., et al. (2003). Cell encapsulation: promise and progress. Nat. Med. 9, 104-107. doi: $10.1038 / \mathrm{nm} 0103-104$

Orive, G., Santos-Vizcaino, E., Pedraz, J. L., Hernandez, R. M., Vela Ramirez, J. E., Dolatshahi-Pirouz, A., et al. (2019). 3D cell-laden polymers to release bioactive products in the eye. Prog. Retin. Eye Res. 68, 67-82. doi: 10.1016/j.preteyeres.2018.10.002

Orive, G., Tam, S. K., Pedraz, J. L., and Halle, J. P. (2006). Biocompatibility of alginate-poly-L-lysine microcapsules for cell therapy. Biomaterials 27, 3691-3700. doi: 10.1016/j.biomaterials.2006.02.048

Paredes-Juarez, G. A., de Haan, B. J., Faas, M. M., and de Vos, P. (2013). The role of pathogen-associated molecular patterns in inflammatory responses against alginate based microcapsules. J. Control. Release 172, 983-992. doi: 10.1016/j.jconrel.2013.09.009

Paredes-Juarez, G. A., de Haan, B. J., Faas, M. M., and de Vos, P. (2014a). A technology platform to test the efficacy of purification of alginate. Materials 7, 2087-2103. doi: 10.3390/ma7032087

Paredes-Juarez, G. A., Sahasrabudhe, N. M., Tjoelker, R. S., de Haan, B. J., Engelse, M. A., de Koning, E. J. P., et al. (2015). DAMP production by human islets under low oxygen and nutrients in the presence or absence of an immunoisolating-capsule and necrostatin-1. Sci. Rep. 5:14623. doi: $10.1038 /$ srep 14623

Paredes-Juarez, G. A., Spasojevic, M., Faas, M. M., and de Vos, P. (2014b). Immunological and technical considerations in application of alginatebased microencapsulation systems. Front. Bioeng. Biotechnol. 2:26. doi: 10.3389/fbioe.2014.00026

Piller Puicher, E., Tomanin, R., Salvalaio, M., Friso, A., Hortelano, G., Marin, O., et al. (2012). Encapsulated engineered myoblasts can cure Hurler syndrome: preclinical experiments in the mouse model. Gene Ther. 19, 355-364. doi: 10.1038 /gt.2011.94

Reyes-Sandoval, A., and Ertl, H. C. (2004). CpG methylation of a plasmid vector results in extended transgene product expression by circumventing induction of immune responses. Mol. Ther. 9, 249-261. doi: 10.1016/j.ymthe.2003.11.008

Ross, C., Clemmesen, K. M., Svenson, M., Sorensen, P. S., Koch-Henriksen, N., Skovgaard, G. L., et al. (2000). Immunogenicity of interferon-beta in multiple sclerosis patients: influence of preparation, dosage, dose frequency, and route of administration. Danish Multiple Sclerosis Study Group. Ann. Neurol. 48, 706-712. doi: 10.1002/1531-8249(200011)48:5<706::AID-ANA3>3.0.CO;2-V

Sato, S., St-Pierre, C., Bhaumik, P., and Nieminen, J. (2009). Galectins in innate immunity: dual functions of host soluble beta-galactoside-binding lectins as damage-associated molecular patterns (DAMPs) and as receptors for pathogen-associated molecular patterns (PAMPs). Immunol. Rev. 230, 172-187. doi: 10.1111/j.1600-065X.2009.00790.x

Sayyar, B., Dodd, M., Marquez-Curtis, L., Janowska-Wieczorek, A., and Hortelano, G. (2014). Cell-matrix Interactions of Factor IX (FIX)-engineered human mesenchymal stromal cells encapsulated in RGD-alginate vs. fibrinogenalginate microcapsules. Artif. Cells Nanomed. Biotechnol. 42, 102-109. doi: 10.3109/21691401.2013.794354

Sayyar, B., Dodd, M., Marquez-Curtis, L., Janowska-Wieczorek, A., and Hortelano, G. (2015). Fibronectin-Alginate microcapsules improve cell viability and protein secretion of encapsulated Factor IX-engineered human mesenchymal stromal cells. Artif. Cells Nanomed. Biotechnol. 43, 318-327. doi: $10.3109 / 21691401.2014 .885446$ 
Sayyar, B., Dodd, M., Wen, J., Ma, S., Marquez-Curtis, L., Janowska-Wieczorek, A., et al. (2012). Encapsulation of factor IX-engineered mesenchymal stem cells in fibrinogen-alginate microcapsules enhances their viability and transgene secretion. J. Tissue Eng. 3:2041731412462018. doi: 10.1177/2041731412462018

Schaefer, L. (2010). Extracellular matrix molecules: endogenous danger signals as new drug targets in kidney diseases. Curr. Opin. Pharmacol. 10, 185-190. doi: 10.1016/j.coph.2009.11.007

Shapiro, A. M., Lakey, J. R., Ryan, E. A., Korbutt, G. S., Toth, E., Warnock, G. L., et al. (2000). Islet transplantation in seven patients with type 1 diabetes mellitus using a glucocorticoid-free immunosuppressive regimen. N. Engl. J. Med. 343, 230-238. doi: 10.1056/NEJM200007273430401

Soon-Shiong, P., Heintz, R. E., Merideth, N., Yao, Q. X., Yao, Z., Zheng, T., et al. (1994). Insulin independence in a type 1 diabetic patient after encapsulated islet transplantation. Lancet 343, 950-951. doi: 10.1016/S0140-6736(94)90067-1

Srivastava, P. (2002). Roles of heat-shock proteins in innate and adaptive immunity. Nat. Rev. Immunol. 2, 185-194. doi: 10.1038/nri749

Strand, B. L., Ryan, T. L., In't Veld, P., Kulseng, B., Rokstad, A. M., Skjak-Brek, G., et al. (2001). Poly-L-Lysine induces fibrosis on alginate microcapsules via the induction of cytokines. Cell Transplant. 10, 263-275. doi: 10.3727/000000001783986800

Susek, K. H., Karvouni, M., Alici, E., and Lundqvist, A. (2018). The role of CXC chemokine receptors 1-4 on immune cells in the tumor microenvironment. Front. Immunol. 9:2159. doi: 10.3389/fimmu.2018.02159

Tabar, V., and Studer, L. (2014). Pluripotent stem cells in regenerative medicine: challenges and recent progress. Nat. Rev. Genet. 15, 82-92. doi: $10.1038 / \operatorname{nrg} 3563$

Tai, K., Pelled, G., Sheyn, D., Bershteyn, A., Han, L., Kallai, I., et al. (2008). Nanobiomechanics of repair bone regenerated by genetically modified mesenchymal stem cells. Tissue Eng. Part A 14, 1709-1720. doi: 10.1089/ten.tea.2007.0241

Tam, S. K., Dusseault, J., Bilodeau, S., Langlois, G., Halle, J. P., and Yahia, L. (2011). Factors influencing alginate gel biocompatibility. J. Biomed. Mater. Res. A 98, 40-52. doi: 10.1002/jbm.a.33047

Tam, S. K., Dusseault, J., Polizu, S., Menard, M., Halle, J. P., and Yahia, L. (2006). Impact of residual contamination on the biofunctional properties of purified alginates used for cell encapsulation. Biomaterials 27, 1296-1305. doi: 10.1016/j.biomaterials.2005.08.027

Tomaro-Duchesneau, C., Saha, S., Malhotra, M., Kahouli, I., and Prakash, S. (2013). Microencapsulation for the therapeutic delivery of drugs, live mammalian and bacterial cells, and other biopharmaceutics: current status and future directions. J. Pharm. 2013:103527. doi: 10.1155/2013/103527

Turgeman, G., Zilberman, Y., Zhou, S., Kelly, P., Moutsatsos, I. K., Kharode, Y. P., et al. (2002). Systemically administered rhBMP-2 promotes MSC activity and reverses bone and cartilage loss in osteopenic mice. J. Cell. Biochem. 86, 461-474. doi: 10.1002/jcb.10231

Uludag, H., De Vos, P., and Tresco, P. A. (2000). Technology of mammalian cell encapsulation. Adv. Drug Deliv. Rev. 42, 29-64. doi: 10.1016/S0169-409X(00)00053-3

Vaithilingam, V., Bal, S., and Tuch, B. E. (2017). Encapsulated islet transplantation: where do we stand? Rev. Diabet. Stud. 14, 51-78. doi: 10.1900/RDS.2017.14.51

Vaithilingam, V., Fung, C., Ratnapala, S., Foster, J., Vaghjiani, V., Manuelpillai, U., et al. (2013). Characterisation of the xenogeneic immune response to microencapsulated fetal pig islet-like cell clusters transplanted into immunocompetent C57BL/6 mice. PLoS ONE 8:e59120. doi: 10.1371/journal.pone.0059120
Vaithilingam, V., Kollarikova, G., Qi, M., Lacik, I., Oberholzer, J., Guillemin, G. J., et al. (2011). Effect of prolonged gelling time on the intrinsic properties of barium alginate microcapsules and its biocompatibility. J. Microencapsul. 28, 499-507. doi: 10.3109/02652048.2011.586067

van Hoogmoed, C. G., Busscher, H. J., and de Vos, P. (2003). Fourier transform infrared spectroscopy studies of alginate-PLL capsules with varying compositions. J. Biomed. Mater. Res. A 67, 172-178. doi: 10.1002/jbm.a.10086

Vaure, C., and Liu, Y. (2014). A comparative review of toll-like receptor 4 expression and functionality in different animal species. Front. Immunol. 5:316. doi: 10.3389/fimmu.2014.00316

Veriter, S., Gianello, P., Igarashi, Y., Beaurin, G., Ghyselinck, A., Aouassar, N., et al. (2014). Improvement of subcutaneous bioartificial pancreas vascularization and function by coencapsulation of pig islets and mesenchymal stem cells in primates. Cell Transplant. 23, 1349-1364. doi: 10.3727/096368913X663550

Wen, J., Vargas, A. G., Ofosu, F. A., and Hortelano, G. (2006). Sustained and therapeutic levels of human factor IX in hemophilia B mice implanted with microcapsules: key role of encapsulated cells. J. Gene Med. 8, 362-369. doi: 10.1002/jgm.852

Wen, J., Xu, N., Li, A., Bourgeois, J., Ofosu, F. A., and Hortelano, G. (2007). Encapsulated human primary myoblasts deliver functional hFIX in hemophilic mice. J. Gene Med. 9, 1002-1010. doi: 10.1002/jgm.1098

Xu, J., Zhang, X., Monestier, M., Esmon, N. L., and Esmon, C. T. (2011). Extracellular histones are mediators of death through TLR2 and TLR4 in mouse fatal liver injury. J. Immunol. 187, 2626-2631. doi: 10.4049/jimmunol.1003930

Yi, S., Hawthorne, W. J., Lehnert, A. M., Ha, H., Wong, J. K., Van Rooijen, N., et al. (2003). T cell-activated macrophages are capable of both recognition and rejection of pancreatic islet xenografts. J. Immunol. 170, 2750-2758. doi: 10.4049/jimmunol.170.5.2750

Yu, J., Du, K. T., Fang, Q., Gu, Y., Mihardja, S. S., Sievers, R. E., et al. (2010). The use of human mesenchymal stem cells encapsulated in RGD modified alginate microspheres in the repair of myocardial infarction in the rat. Biomaterials 31 7012-7020. doi: 10.1016/j.biomaterials.2010.05.078

Yu, X., Wang, D., Wang, X., Sun, S., Zhang, Y., Wang, S., et al. (2019). CXCL12/CXCR4 promotes inflammation-driven colorectal cancer progression through activation of RhoA signaling by sponging miR-133a-3p. J. Exp. Clin. Cancer Res. 38:32. doi: 10.1186/s13046-018-1014-x

Zhong, F., and Jiang, Y. (2019). Endogenous pancreatic beta cell regeneration: a potential strategy for the recovery of beta cell deficiency in diabetes. Front. Endocrinol. 10:101. doi: 10.3389/fendo.2019.00101

Zurn, A. D., Henry, H., Schluep, M., Aubert, V., Winkel, L., Eilers, B., et al. (2000). Evaluation of an intrathecal immune response in amyotrophic lateral sclerosis patients implanted with encapsulated genetically engineered xenogeneic cells. Cell Transplant. 9, 471-484. doi: 10.1177/096368970000900404

Conflict of Interest: The authors declare that the research was conducted in the absence of any commercial or financial relationships that could be construed as a potential conflict of interest.

Copyright (c) 2019 Ashimova, Yegorov, Negmetzhanov and Hortelano. This is an open-access article distributed under the terms of the Creative Commons Attribution License (CC BY). The use, distribution or reproduction in other forums is permitted, provided the original author(s) and the copyright owner(s) are credited and that the original publication in this journal is cited, in accordance with accepted academic practice. No use, distribution or reproduction is permitted which does not comply with these terms. 